\title{
Profil Hematologi Sederhana pada Trenggiling Jawa (Manis Javanica) yang Mengalami Diare Kronis
}

\author{
Muhammad Sulthan Rasyid Rifai ${ }^{1}$, Chusnul Choliq ${ }^{2} *$, Chairun Nisa' ${ }^{3}$, \\ Danny Umbu Tay Hambandima ${ }^{4}$ \\ ${ }^{1}$ Program Sarjana Kedokteran Hewan, Fakultas Kedokteran Hewan, Institut Pertanian Bogor \\ ${ }^{2}$ Departemen Klinik Reproduksi dan Patologi, Fakultas Kedokteran Hewan Institut Pertanian Bogor \\ ${ }^{3}$ Departemen Anatomi Fisiologi dan Farmakologi, Fakultas Kedokteran Hewan, Institut Pertanian Bogor \\ ${ }^{4}$ Rumah Sakit Hewan Pendidikan, Fakultas Kedokteran Hewan, Institut Pertanian Bogor
}

ABSTRAK: Seekor trenggiling jawa (Manis javanica) jantan berusia lima tahun menderita diare kronis selama dua bulan. Pemeriksaan hematologi dilakukan secara manual untuk mengetahui kondisi fisiologis trenggiling dengan parameter Red Blood Cell (RBC), White Blood Cell (WBC), Packed Cell Volume (PCV), hemoglobin (Hb), indeks RBC, dan diferensial WBC. Trenggiling diidentifikasi mengalami polisitemia relatif, dehidrasi, anemia mikrositik-normokromik, indikasi hipoksia, dan neutrofilia. Kondisi ini disebabkan oleh diare kronis akibat infeksi multi kausa dengan didominasi oleh infeksi bakteri yang menyebabkan trenggiling mengalami malnutrisi dan stres secara fisik dan fisiologis.

Kata kunci:

diare, hematologi, trenggiling jawa

\section{- PENDAHULUAN}

Trenggiling jawa (Manis javanica) merupakan hewan mamalia langka yang berasal dari Asia Tenggara. Hewan ini dilindungi oleh Pemerintah Indonesia, berdasarkan Peraturan Pemerintah (PP) Nomor 7 tahun 1999 dan UndangUndang (UU) Nomor 5 tahun 1990. Trenggiling jawa juga masuk dalam Red List oleh International Union for the Conservation of Nature (IUCN) dan termasuk kategori critically endangered species (IUCN 2014).

Seekor trenggiling jawa menderita diare kronis selama kurun waktu dua bulan. Pemeriksaan hematologi sederhana dilakukan untuk medapatkan gambaran dari kondisi darah pada trenggiling yang sakit. Profil hematologi sederhana akan memberikan gambaran klinis secara kasar terhadap kondisi fisiologis trenggiling dengan kondisi klinis diare kronis. Hal ini dilakukan untuk membantu meneguhkan diagnosa terhadap kemungkinan terjadinya penyakit dan untuk membantu menentukan tindakan medis yang sesuai. Parameter yang termasuk ke dalam hematologi sederhana adalah Red Blood Cell (RBC), White Blood Cell (WBC), Packed Cell Volume (PCV), hemoglobin ( $\mathrm{Hb})$, indeks eritrosit, dan diferensial leukosit (Davey 2002).

\section{- KEJADIAN KASUS}

Seekor trenggiling jawa jantan berumur kurang lebih lima tahun dikandangkan untuk keperluan penelitian mengenai pakan pengganti dan perilaku reproduksi. Trenggiling men- derita diare kronis selama kurun waktu dua bulan di kandang pemeliharaan dengan frekuensi satu sampai dua kali sehari dan konsistensi sangat encer. Kejadian diare ini diikuti dengan penurunan berat badan secara drastis (kaheksia) dan ketidakmampuan trenggiling untuk bergerak (letargi), namun trenggiling masih memiliki nafsu makan yang baik. Trenggiling kemudian dibawa ke Rumah Sakit Hewan Pendidikan (RSHP), Institut Pertanian Bogor (IPB) untuk dilakukan perawatan. Darah trenggiling diambil melalui vena coxygea.

\section{- HASIL DAN PEMBAHASAN}

Pemeriksaan hematologi sederhana menunjukkan nilai yang cenderung normal. Pada Tabel 1, parameter sel darah merah (RBC) menunjukkan adanya peningkatan dari nilai normalnya atau disebut polisitemia (Cotter 2001). Polisitemia pada kasus ini kemungkinan merupakan jenis polisitemia relatif karena mengikuti kejadian diare yang menyebabkan dehidrasi pada trenggiling. Menurut Rapaport (1987), polisitemia relatif merupakan penurunan volume plasma darah sehingga seakan-akan terjadi peningkatan massa RBC. Pemeriksaan Packed Cell Volume (PCV) pada juga menun-

$\begin{array}{ll}\text { Diterima } & : 28 \text { Juli } 2017 \\ \text { Direvisi } & : 14 \text { Agustus } 2017 \\ \text { Disetujui } & : 16 \text { Agustus } 2017\end{array}$ 
jukkan nilai yang normal. PCV yang memiliki nilai tinggi dapat menunjukkan indikasi bahwa hewan mengalami dehidrasi, sedangkan PCV yang rendah dapat menunjukkan indikasi bahwa hewan mengalami anemia (Cotter 2001). Hasil pemeriksaan hemoglobin $(\mathrm{Hb})$ menunjukkan nilai yang relatif normal. Kadar RBC yang mengalami peningkatan seharusnya diikuti dengan peningkatan kadar $\mathrm{Hb}$ pada kondisi normal. Dalam kondisi ini, $\mathrm{Hb}$ cenderung normal namun mendekati batas bawah nilai normal, sehingga ada indikasi oksigen yang beredar di darah dalam jumlah yang sedikit. Hal ini sesuai dengan pendapat Cunningham (1997) yang menyatakan bahwa $\mathrm{Hb}$ memiliki fungsi utama sebagai pengangkut oksigen dan karbondioksida.

Tabel 1. Profil hematologi trenggiling yang mengalami diare kronis.

\begin{tabular}{|c|c|}
\hline Parameter & Nilai yang didapat \\
\hline $\mathrm{RBC}\left(\mathbf{1 0}^{\mathbf{6}} / \mu \mathrm{L}\right)$ & 8.14 \\
$\mathrm{PCV}(\%)$ & 35 \\
$\mathrm{Hb}(\mathrm{g} / \mathrm{dL})$ & 9.2 \\
$\mathrm{MCV}(\mathrm{fl})$ & 43 \\
$\mathrm{MCH}(\mathrm{pg})$ & 11.3 \\
$\mathrm{MCHC}(\mathrm{gr} \%)$ & 26.3 \\
$\mathrm{WBC}(\mathbf{1 0} / \mu \mathrm{L})$ & 5.9 \\
$\mathrm{Limfosit}(\%)$ & 29 \\
Monosit (\%) & 5 \\
Neutrofil $(\%)$ & 67 \\
Eosinofil $(\%)$ & 6 \\
Basofil (\%) & 3 \\
\hline
\end{tabular}

Keterangan: $\mathrm{RBC}=$ red blood cell, $\mathrm{PCV}=$ packed cell volume, $\mathrm{Hb}=$ haemoglobin, $\mathrm{MCV}=$ mean corpuscular volume, $\mathrm{MCH}=$ mean corpuscular haemoglobin, $\mathrm{MCHC}=$ mean corpuscular haemoglobin concentration, $\mathrm{WBC}=$ white blood cell.

Mean Corpuscular Volume (MCV), Mean Corpuscular Haemoglobin (MCH), dan Mean Corpuscular Haemoglobin Concentration (MCHC) merupakan indeks RBC untuk penentuan jenis anemia (Cotter 2001). Nilai MCV dan MCH lebih rendah dari batas nilai normal, sedangkan MCHC menunjukkan nilai yang normal namun berada di kisaran rendah. $\mathrm{MCH}$ yang rendah mengindikasikan adanya hipoksia karena perbandingan hemoglobin dan RBC yang jauh. Menurut Davey (2002), MCV yang rendah menunjukkan adanya anemia mikrositik, sedangkan MCHC yang normal menunjukkan anemia normokromik. Anemia mikrositiknormokromik dapat disebabkan oleh defisiensi zat besi $(\mathrm{Fe})$, vitamin B12, dan komplikasi penyakit kronis (Davey 2005). Trenggiling dalam kasus ini diduga mengalami defisiensi $\mathrm{Fe}$, vitamin $\mathrm{B} 12$, dan beberapa protein pembentuk darah karena malnutrisi akibat diare kronis.

Parameter sel darah putih (WBC) menunjukkan nilai yang juga normal. WBC berperan dalam mekanisme perta- hanan tubuh dari benda asing yang masuk ke dalam tubuh (Cotter 2001). Pemeriksaan diferensial WBC menunjukkan neutrofil lebih dominan dari pada WBC lain, dan WBC jenis lain masih berada pada kisaran nilai normal. Neutrofil lebih banyak berperan dalam pertahanan tubuh untuk infeksi mikroba (Campbell et al. 2004). Hal ini menunjukkan kemungkinan bahwa infeksi bakteri pada saluran pencernaan trenggiling pada kasus ini lebih dominan dari pada infeksi parasit.

\section{SIMPULAN}

Pemeriksaan profil hematologi sederhana dilakukan untuk mengetahui kondisi fisiologis trenggiling yang mengalami diare kronis. Profil hematologi menunjukkan kondisi polisitemia, anemia mikrositik-normokromik, indikasi hipoksia, dan neutrofilia. Kondisi-kondisi tersebut disebabkan oleh keadaan stres, dehidrasi, dan malnutrisi akibat diare kronis.

\section{n INFORMASI PENULIS}

Penulis untuk Korespondensi

noelch08@gmail.com

\section{- UCAPAN TERIMA KASIH}

Penulis mengucapkan terima kasih kepada Rumah Sakit Hewan Pendidikan IPB, Pusat Studi BiofarmakaTropika LPPM IPB, Lembaga Ilmu Pengetahuan Indonesia, dan Ditjen PHKA Kementerian Lingkungan Hidup \& Kehutanan.

\section{- PUSTAKA ACUAN}

Campbell NA, Reece JB, Mitchell LG. 2004. Biologi, Edisi Kelima Jilid III. Manalu W, penerjemah; Safitri A, editor. Jakarta (ID): Penerbit Erlangga. Terjemahan dari : Biology.

Chhetri RK, Sun CM, Wu HY, Pei KJC. 2015. Refference intervals for hematology, serum biochemistry, and basic clinical findings in free-ranging Chinese Pangolin (Manis pentadactyla) from Taiwan. Vet Clin Pathol. 44(3): 380-390.

Cotter SM. 2001. Hematology. South King Street (US) : Teton New Media. 150 halaman.

Cunningham JD. 1997. Text Book of Veterinary Physiology. Philadelphia (US): WB Saunders Co.

Davey P. 2005. At a Glance Medinice. Jakarta (ID) : Penerbit Erlangga. 430 halaman.

[IUCN] International Union for the Conservation of Nature. 2014. Manis javanica. Tersedia pada: www.iucnredlist.org/details/12763/0 [30 Desember 2016].

Mohapatra RK, Mohanty PK, Panda S. 2014. Haematological, biochemical, and cytomorphometric, analysis of an indian pangolin. Int. Res. J. Biological Sci. 3(8): 77-81.

Rapaport SI. 1987. Introduction to Hematology Ed 2. Philadelphia (US): J.B. Lippincott Company. Halaman 194. 